\title{
Wilkie's syndrome. Analysis of 150 cases of the Iberian and Ibero-American medical literature.
}

\author{
E«equiel Trejo Scoræa ${ }^{1}$, Oscar Luis Colina Cedeño ${ }^{1}$, Edgar José Brito Arreaza ${ }^{1}$ \\ and Carlos José Trejo Scoræa ${ }^{2}$ \\ ${ }^{1}$ Centro Médico de Caracas, and Escuela de Medicina "Luis Razetti", Facultad \\ de Medicina, Universidad Central de Venezuela, Caracas, Venezuela. \\ ${ }^{2}$ Clínica "La Floresta", Caracas, Venezuela.
}

Key words: Wilkie's syndrome; vascular compression of the duodenum; obstruction duodenal; superior mesenteric artery syndrome.

\begin{abstract}
Willkie's syndrome or superior mesenteric artery (SMA) syndrome is a rare cause of gastrointestinal obstruction, due to exterior compression of the horizontal part of the duodenum by the SMA. For the study of the clinical, diagnostic and therapeutic characteristics of Wilkie's syndrome in the Iberian and Ibero-American population, we compiled the reports of 150 cases by Iberican and Ibero-American authors, and we found a predominance of cases in females over males in a ratio of 2.57: 1 . Fifty percent of the cases were in patients under 20-years of age, with the highest number of cases in schoolchildren and adolescents. The most frequent symptoms were abdominal pain, vomiting and weight loss. The disease had two forms of presentation: acute with signs of high intestinal obstruction (16.47\%), and chronic (83.53\%). Diagnostic radiographic studies showed in of the upper gastrointestinal tract narrowing of the horizontal portion of the duodenum and delay in the transit of contrast through the gastroduodenal region, with or without gastroduodenal dilation in $85 \%$ of cases. In computed tomographic studies it was observed decreased mesenteric-aortic angle and distance. Upper endoscopic studies showed narrowing of the horizontal part of the duodenum, with or without gastroduodenal dilation in $61.90 \%$ of cases. Of the 144 patients that received treatment, 94 cases received medical treatment, with a success rate of $62.77 \%$; and 84 cases required surgical treatment, 59.52\% of these, upon admission. The most practiced surgical procedure was laterolateral duodenojejunostomy in $70.24 \%$ of cases. We concluded that Wilkie's syndrome is an entity that results from the reduction of the mesenteric-aortic angle and distance, with two forms of presentation: acute and chronic, that required surgical treatment in $58.33 \%$ of cases.
\end{abstract}

Corresponding author: Ezequiel Trejo-Scorza. "Centro Médico" of Caracas, and Escuela de Medicina "Luis Razetti”, Facultad de Medicina, Universidad Central de Venezuela, Caracas, Venezuela. E-mail: trejoscorza@gmail.com 


\title{
Sindrome de Wilkie. Análisis de 150 casos de la literatura Ibérica e Ibero-americana.
}

\author{
Invest Clin 2020; 61 (3): 242-264
}

Palabras clave: Síndrome de Wilkie; compresión vascular del duodeno; obstrucción duodenal; síndrome de la arteria mesentérica superior.

Resumen. El síndrome de Wilkie o síndrome de la arteria mesentérica (AMS) es una causa poco común de obstrucción gastrointestinal, debido a la compresión externa de la parte horizontal del duodeno por la AMS. Para el estudio de las características clínicas, diagnósticas y terapéuticas del síndrome de Wilkie en la población ibérica e iberoamericana, analizamos los reportes de 150 casos por autores ibéricos e iberoamericanos, y encontramos un predominio de casos de sexo femenino sobre el masculino en una proporción de 2,57: 1. El 50\% de los casos ocurrieron en menores de 20 años, con el mayor número de casos en escolares y adolescentes. Los síntomas más frecuentes fueron dolor abdominal, vómitos y pérdida de peso. La enfermedad tuvo dos formas de presentación: aguda con signos de obstrucción del intestino superior $(16,47 \%)$ y crónica $(83,53 \%)$. Los estudios de diaǵnóstico radiográfico mostraron en el tracto gastrointestinal superior: estrechamiento de la porción horizontal del duodeno y retraso en el tránsito del contraste a través de la región gastroduodenal con o sin dilatación gastroduodenal en $85 \%$ de los casos; en tomografía computarizada: disminución del ángulo y la distancia aórtica mesentérica; y en endoscopia superior: estrechamiento de la parte horizontal del duodeno, con o sin dilatación gastroduodenal en $61,90 \%$. De los 144 pacientes que recibieron tratamiento, 94 casos recibieron tratamiento médico, con una tasa de éxito del 62,77\%; y 84 casos requirieron tratamiento quirúrgiico, 59,52\% de estos, al ingreso. El procedimiento quirúrgíco más practicado fue la duodenoyeyunostomía laterolateral en 70,24\%. Concluimos que el síndrome de Wilkie es una entidad que resulta de la reducción del ángulo y de la distancia mesentérica aórtica, con dos formas de presentación: aguda y crónica. Se requirió tratamiento quirúrǵico en el $58,33 \%$ de los casos.

Received: 31-03-2020Ａccepted: 15-07-2020

\section{INTRODUCTION}

The constriction of the horizontal part of the duodenum by the root of the mesentery or Wilkie's syndrome, is also known as vascular compression of the duodenum, superior mesenteric artery syndrome, aortomesenteric clamp syndrome, cast syndrome, arteriomesenteric duodenal compression, arterio- mesenteric ileus, gastro-mesenteric ileus, chronic duodenal ileus, arterio-mesenteric duodenal obstruction and mesenteric-aortic impingement. It results, in partial or total obstruction of the horizontal part of the duodenum, and its clinical manifestations are abdominal pain, vomiting, weight loss, and sometimes, abdominal distension. It is an uncommon entity and can compromise the 
patient's life. Due to its low frequency, it is little known, and thus is not included among the first diagnostic possibilities, which delays the diagnosis and proper treatment. Most authors point out that Rokitansky, was the first to describe the compression of the horizontal part of the duodenum by the superior mesenteric artery, in 1861; but Bermanski et al (1), who presented a complicated case by pancreatitis and performed a very complete historical review, indicated that: 1 .- the first description of the superior mesenteric artery syndrome was made by Boernerus in 1752 ; 2.- Rokitansky in 1842 , described the acute dilation of the stomach resulting from compression of the duodenum by the root of the mesentery. 3.- Stavely, in 1910 was the first to practice a successful duodenojejunostomy in a patient with gastro-mesenteric ileus. Wilkie in 1921 (2), presented four cases and concluded that: 1.- the compression of the horizontal part of the duodenum by the root of the mesentery is a true clinical and pathological entity; 2.- the most proper treatment is drainage of the duodenum by duodenojejunostomy. In 1927 (3) he presented a series of 75 cases, where the female sex predominated in a ratio of 2.26: 1 and the youngest patient was a 7 -year-old boy. Of these, 64 cases were operated by the author, and 57 with follow-up with significant cure or improvement in about $81 \%$ of the cases. After these papers' publication, this disease is known worldwide as Wilkie's Syndrome.

We reviewed the papers published on children cases (4-8) and found that: 1.- The compression of the horizontal part of the duodenum by the superior mesenteric artery represents $23 \%$ of extrinsic causes and 15\% of the total causes of duodenal obstruction. 2.- the surgical treatment that combines the lowest morbidity and the earliest recovery of the gastrointestinal function, consists in the duodenal derotation procedure (mobilization, and placement of the duodenum in the right paravertebral canal), proposed by Louw in 1957. This surgical technique is similar to what is done in the Ladd procedure for intestinal malrotation, but the mesentery in the region of the ileocecal valve and the lateral unions of the ascending colon, should be left joined to the retroperitoneum to prevent volvulus of the middle intestine.

We reviewed the world medical literature on this syndrome and were able to compile and analyze the papers published by Iberian and Ibero-American authors, regardless of the language of publication of the papers (Spanish, Portuguese or English). We found 58 papers in Latin America with reports of 78 cases (9-66), and 44 papers with 72 cases (67-110) in the Iberian Peninsula; for a total of 102 papers with 150 cases. In all these papers, we reviewed and analyzed the epidemiology, etiopathogenesis, clinical, diagnostic, therapeutic procedures and the results obtained.

\section{MATERIALS AND METHODS}

Through the search engines of medical papers PubMed, Lilacs, Scielo, Medes, Dialnet, Medigraphic, using the search criteria: Wilkie's Syndrome and Superior Mesenteric Artery Syndrome, we found 106 publications of Iberian and Ibero-American authors and were able to access 102 of them. We reviewed the data of all patients reported with Wilkie's Syndrome diagnosis in the 102 reviewed publications. The data extracted and analyzed included sex, age, symptoms presented, medical and surgical history, duration of symptoms, means of diagnosis and findings, treatment and results. For its analysis, all the information was entered into a spreadsheet of the LibreOffice program (Version: 6.1.5.2 Build ID: 1:6.1.5-3+deb10u5; OS: Linux 4.19) and divided them into three groups: a) those that responded to medical treatment, b) those who did not responded to medical treatment and needed surgical treatment, and c) those who needed surgical treatment upon admission. 


\section{RESULTS}

1. Sex: Of the 150 cases, 108 (72\%) were in females and 42 (28\%) were in males, with a predominance of females over males in a proportion of 2.57 .

2. Age: The age range was from one day of life to 83 years of age, with an average of 26.093 years. Two cases were in newborns, both females $(40,66)$. The distribution by age is shown in Fig. 1 . We found that 75 cases $(50.00 \%)$ were diagnosed before 20 years of age and the highest number of cases (66 eases) in schoolchildren and adolescents that together represent $88 \%$ of cases in pediatric ages. See Fig. 2. The high incidence in adolescents seems to be due to rapid growth without weight gain $(7,8)$.

3. Medical-surgical background and associated pathologies: Of the 150 patients, $53(35.33 \%)$ presented medical-surgical background and associated pathologies which we grouped into four categories:

4. a. Patients with weight loss were 24 cases and their causes are shown in Table I. b. Patients with anatomical causes that decreased the aortomesenteric distance were 17 eases and their causes are shown in Table II. c. Patients with personal or family histories were four cases: family history of Wilkie's Syndrome (1 case); Raynaud's syndrome history and psychological disor-

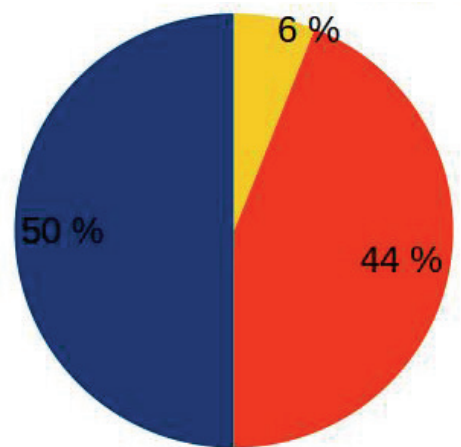

- Under 20 years-old - 20-59 years-old $=60-89$ years-old

Fig. 1. Shows the distribution for age groups: $50 \%$ of the patients were diagnosed before 20 years of age.

ders manifested by depression and anxiety ( 1 case); personal medical history of Wilkie's Syndrome and celiac disease (1 case); and family history of adenomatous polyposis, who underwent ileoanal anastomosis, which was the cause of the vascular compression of the duodenum (1 case). d. Patients with histories of many surgical interventions on the abdominal cav$i t y$ were five cases and in all of them, the symptoms persisted and only disappeared when an enteric bypass procedure was practiced: duodenojejunostomy in four cases, and gastrojejunostomy in Y of Roux in one case.

5. Clinical manifestations: we were able to collect the time of appearance of symptoms in 85 cases, and ranged from 12 hours to 27 years, manifesting in hours one case, in days 13 cases, in months 39 cases and in years 32 cases. In the 150 cases analyzed, we found the symptoms shown in Table III, and as you can see, the most frequent were abdominal pain, vomiting and weight loss. Abdominal pain of epigastric location and of postprandial apparition, which was sometimes reported as fullness or postprandial discomfort, which calmed down with vomiting, which could be occasional or incoercible. Vomiting was reported as bilious in 41 (36.28\%) of the 113 cases with this symptom. The sum of the incidence of the symptoms: food intolerance, nausea and vomiting accounted for 119 patients (79.33\%). Weight loss occurred in $48.67 \%$ and abdominal distension in $18.00 \%$. Abdominal distention when it occurred was a sign of massive gastric dilation as showed the radiological studies. We divided the patients depending on the required treatment, into three groups: a) Those who responded to medical treatment: 60 patients, b) those who did not respond to medical treatment and needed surgical treatment: 34 patients and c) those who needed 


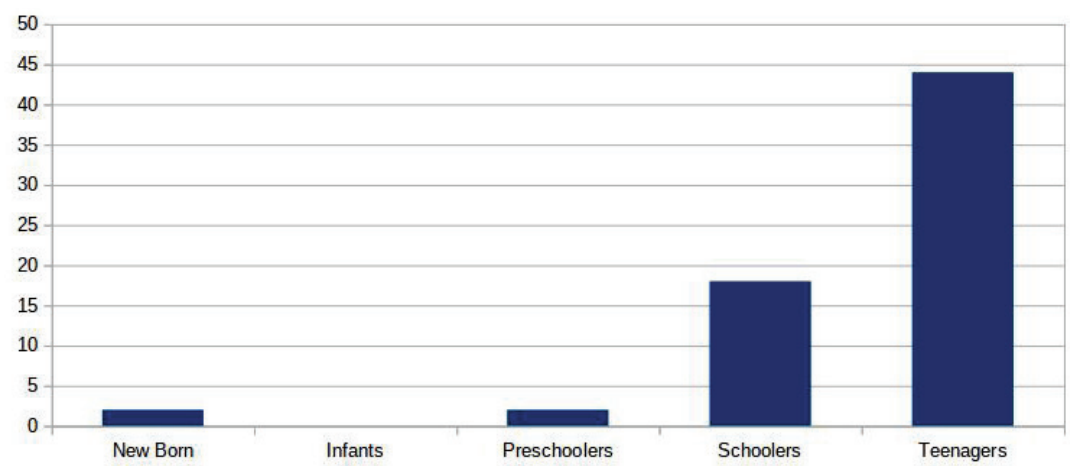

Fig. 2. Shows the age distributions in pediatric patients. The schoolchildren and adolescents together represent $88 \%$ of cases in pediatric ages.

TABLE I

WILKIE'S SYNDROME. CAUSES OF WEIGHT LOSS.

\begin{tabular}{|c|c|}
\hline CAUSES & Number of cases and percentage \\
\hline Anorexy & $5(20.83 \%)$ \\
\hline Disablinǵ neurological diseases & $5(20.83 \%)$ \\
\hline Low-calorie diets & $4(16.67 \%)$ \\
\hline Oncological diseases & $3(12.50 \%)$ \\
\hline Endocrine diseases (hyperthyroidism) & $2(8.33 \%)$ \\
\hline $\begin{array}{l}\text { Plastic surgery (patients undergo diets with losing weight before } \\
\text { plastic surgery) }\end{array}$ & $2(8.33 \%)$ \\
\hline Burns & $1(4.17 \%)$ \\
\hline Debilitating diseases and chronic infections & $2(8.33 \%)$ \\
\hline $\begin{array}{l}\text { Repetitive episodes of lung infection; hepatitis at age 16; } \\
\text { chickenpox in childhood; disseminated herpes simplex; } \\
\text { autoimmune hemolytic anemia and bronchiectasis }\end{array}$ & 1 \\
\hline $\begin{array}{l}\text { Chronic malnutrition exacerbated and family history of } \\
\text { tuberculosis and abdominal tuberculosis demonstrated by } \\
\text { lymph node biopsy }\end{array}$ & 1 \\
\hline
\end{tabular}

TABLE II

WILKIE'S SYNDROME. ANATOMICAL CAUSES THAT DECREASED THE DISTANCE AORTOMESENTERIC.

\begin{tabular}{lcc}
\hline CAUSES & Number of cases & Percentage \\
$\begin{array}{l}\text { Diseases of the spine, or orthopedic or surgical procedures } \\
\text { on the spine }\end{array}$ & 10 & $58.82 \%$ \\
$\begin{array}{l}\text { Peripheral vascular diseases } \\
\text { Previous surgical interventions (ileoanal anastomosis) }\end{array}$ & $\begin{array}{c}\text { (Abdominal aortic } \\
\text { aneurysms } 4)\end{array}$ & $29.41 \%$ \\
A large mass located in the hepatic anǵle of the colon (colon & 1 & $5.88 \%$ \\
ad & 1 & $5.88 \%$
\end{tabular}
adenocarcinoma) The tumor that pulled and tensed from the transverse mesocolon eausing the duodenal compression. 
TABLE III

WILKIE'S SYNDROME. CLINICAL MANIFESTATIONS.

\begin{tabular}{lcc}
\hline $\begin{array}{l}\text { Clinical } \\
\text { manifestations }\end{array}$ & $\begin{array}{c}\text { Number } \\
\text { of cases }\end{array}$ & Percentage \\
\hline Abdominal pain & 114 & $76 \%$ \\
Vomiting & 113 & $75.33 \%$ \\
Bilious vomiting & $\begin{array}{c}41(36.28 \%) \\
\text { of the } 113 \text { cases } \\
\text { with vomiting }\end{array}$ \\
\hline $\begin{array}{l}\text { Nausea } \\
\text { Food intolerance }\end{array}$ & 5 & $3.33 \%$ \\
$\begin{array}{l}\text { Weight loss } \\
\text { Abdominal } \\
\text { distension }\end{array}$ & 73 & $0.67 \%$ \\
\hline
\end{tabular}

surgical treatment upon admission: 50 patients. We excluded six patients, five in which the treatment received was not specified and one that died before being able to receive the treatment. The clinical manifestations of each of these groups are shown in Table IV. The incidence of vomiting and weight loss were more frequent in patients who required surgical treatment as you can see in Table V. Bilious vomiting was more frequent in patients who need surgical treatment upon admission. When we applied the Chi-square test to each of the clinical manifestations (pain, vomiting, and weight loss) in the three groups studied, to predict what symptoms could establish the need for surgical treatment, the Chi-square values obtained were: for pain 1,105824541 , for vomiting 11,051156656 and for weight loss 18,78133536 . As the value of the degrees of freedom was 2 and the reliability of $99 \%$, the critical value corresponded to 18,4662 and the only value of the Chi-square test that exceeded the critical value, was the value of Chisquare test for weight loss.

6. The diagnostic studies performed were simple standing X-ray of abdomen (24 cases), upper gastrointestinal tract radiography (100 eases), upper gastrointestinal tract endoscopy (42 cases), computed tomography (CT) (74 eases), magnetic resonance imaging (MRI) (3 cases), arteriography (2 cases), abdominal ultrasound (29 cases), diagnostic laparoscopy (1 case). The results of the radiological and endoseopic studies are shown in Tables VI, VII and VIII. Beloware shown the most frequent findings ineach of the diagnosticstudies performed: a. - Standing X-ray of the abdomen showed gastric dilation, accompanied or not by duodenal dilation, in $62.50 \%$ of eases. b.- Upper gastrointestinal tract radiography showed the narrowing of the horizontal part of the duodenum and delay in contrast transit through the gastroduodenal region accompanied or not by gas-

TABLE IV

WILKIE'S SYNDROME.CLINICAL MANIFESTATIONS BY GROUPS.

\begin{tabular}{lcccc}
\hline & Abdominal pain & Vomiting & Weight loss & Total Patients \\
\hline $\begin{array}{l}\text { Patients responded to } \\
\text { medical treatment }\end{array}$ & $47(42.34 \%)$ & $39(34.51 \%)$ & $17(23.94 \%)$ & $60(41.67 \%)$ \\
$\begin{array}{l}\text { Patients did not respond } \\
\text { to medical treatment and } \\
\text { needed surgical treatment }\end{array}$ & $24(21.62 \%)$ & $30(26.55 \%)$ & $20(28.16 \%)$ & $34(23.61 \%)$ \\
$\begin{array}{l}\text { Patients needed surgical } \\
\text { treatment upon admission }\end{array}$ & $40(36.03 \%)$ & $44(38.93 \%)$ & $34(47.89 \%)$ & $50(34.72 \%)$ \\
Total & 111 & 113 & 71 & 144
\end{tabular}

Vol. 61(3): $242-264,2020$ 


\section{TABLE V \\ WILKIE'S SYNDROME. CLINICAL MANIFESTATIONS IN PATIENTS THAT RESPONDED \\ TO MEDICAL TREATMENT VS GLINICAL MANIFESTATIONS IN PATIENTS THAT NEEDED SURGICAL TREATMENT.}

\begin{tabular}{lcccc}
\hline & Abdominal pain & Vomiting & Weight loss & Total Patients \\
\hline $\begin{array}{l}\text { Patients responded } \\
\text { to medical treatment }\end{array}$ & $47(42.34 \%)$ & $39(34.51 \%)$ & $17(23.94 \%)$ & $60(41.67 \%)$ \\
$\begin{array}{l}\text { Patients needed } \\
\text { surgical treatment }\end{array}$ & $64(57.66 \%)$ & $74(65.49 \%)$ & $54(76.06 \%)$ & $84(58.33 \%)$ \\
Total & 111 & 113 & 71 & 144 \\
\hline
\end{tabular}

TABLE VI

WILKIE'S SYNDROME. RADIOLOGICAL FINDINGS IN THE X-RAYS OF THE STANDING ABDOMEN IN 24 CASES.

\begin{tabular}{lcc}
\hline Radiological findings found & Number of cases & Percentage \\
\hline Gastric dilatation & $\begin{array}{c}13 \text { (two cases with } \\
\text { significant gastric } \\
\text { dilatations) }\end{array}$ & $54.17 \%$ \\
Gastric and duodenal dilatation & 2 & $8.33 \%$ \\
Air-fluid level in upper abdomen and gastric chamber distension & 2 & $8.33 \%$ \\
Air-fluid level in right iliac fossa & 1 & $4.17 \%$ \\
Double bubble image & 1 & $4.17 \%$ \\
Dilatation loop small intestine & 1 & $4.17 \%$ \\
Intestinal pneumatosis & 1 & $4.17 \%$ \\
Study reported without alterations or inconclusive & 3 & $12.50 \%$ \\
Total & 24 & $100 \%$ \\
\hline
\end{tabular}

\section{TABLE VII}

WILKIE'S SYNDROME. RADIOLOGICAL FINDINGS IN THE UPPER GASTROINTESTINAL TRACT RADIOGRAPHS IN 101 CASES.

\begin{tabular}{lcc}
\hline Radiological findings & Number of cases & Percentage \\
\hline $\begin{array}{l}\text { Gastroduodenal dilatation with duodenal constriction } \\
\text { and delay in contrast transit }\end{array}$ & 50 & $50 \%$ \\
Duodenal constriction and delay in contrast transit & 35 & $35 \%$ \\
Gastroduodenal dilatation & 11 & $11 \%$ \\
Study reported as normal & 02 & $2 \%$ \\
Radiological findings suǵgestive of Wilkie's syndrome & 01 & $1 \%$ \\
Duodenal ulcer with delay in contrast transit & 01 & $1 \%$ \\
Total & 100 & $100 \%$
\end{tabular}




\section{TABLE VIII}

WILKIE'S SYNDROME. FINDINGS FOUND IN UPPER DIGESTIVE TRACT ENDOSCOPY IN 42 CASES.

\begin{tabular}{lcc}
\hline Findings & Number of cases & Percentage \\
\hline $\begin{array}{l}\text { Gastroduodenal dilatation with narrowing of the horizontal } \\
\text { part of the duodenum }\end{array}$ & 13 & $30.95 \%$ \\
Narrowing of the horizontal part of the duodenum & 13 & $30.95 \%$ \\
Gastroduodenal dilatation & 03 & $7.14 \%$ \\
Stomach operated Billroth I & 01 & $2.38 \%$ \\
Gastric cancer & 01 & $2.38 \%$ \\
Gastritis and gastroduodenitis & 04 & $9.52 \%$ \\
Bile inside the stomach & 01 & $2.38 \%$ \\
Gastric stasis & 03 & $7.14 \%$ \\
Phytobezoar in the duodenum & 01 & $2.38 \%$ \\
Study reported as normal & 02 & $4.76 \%$ \\
Total & 42 & $100 \%$ \\
\hline
\end{tabular}

troduodenal dilation in the $85 \%$ of eases. c.- Computed tomography showed: the aortomesenteric angle was reported diminished, without indicating its valor in 9 cases. In 37 cases the valor of the aortomesenteric angle was reported with precision, varying between $6^{\circ}$ to $40^{\circ}$ and with an average of $16.1^{\circ}$. In the rest of the 11 cases, the valor of the aortomesenteric angle was reported as follows: less than $13^{\circ}$ (one case), less than $15^{\circ}$ (one case), less than $20^{\circ}$ (six cases) and less than $25^{\circ}$ (three cases). The aortomesenteric distance was reported diminished, without indicating its valor in 14 cases, one of them with an aneurysm. The valor of the aortomesenteric distance was reported in 22 cases. In 19 cases the valor of aortomesenteric distance was reported with precision, varying between from $0.53 \mathrm{~mm}$ to $10.5 \mathrm{~mm}$ with an average of $4.38 \mathrm{~mm}$. In three cases the valor of the aortomesenteric distance was reported as follows: less than $5 \mathrm{~mm}$, between 4 and $5 \mathrm{~mm}$, and between 6 and $8 \mathrm{~mm}$. d.- Upper gastrointestinal tract endoscopy showed the narrowing of the horizontal part of the duodenum, accompanied or not by gastroduodenal dilation in the $61.90 \%$. e.- Magnetic resonance imaging was practiced in three cases, reporting the value of the aortomesenteric angle in two cases $\left(10^{\circ}\right.$ and $\left.17^{\circ}\right)$ and in the remaining case, they reported extrinsic compression of the horizontal part of the duodenum. f.- Arteriography in two cases, the aortomesenteric angle was reported diminished, without indicating its valor. g. - Abdominal ultrasound was performed in 29 cases, showing bowel dilation in 13 cases, decreased aortomesenteric angle in three cases, decreased aortomesenteric distance two cases in both of $3 \mathrm{~mm}$, compression of the horizontal part of the duodenum one case and pneumobilia and fluid in pelvis one case. h.- Diagnostic laparoscopy in one case revealed extrinsic compression of the duodenum by the mesenteric vessels at the level of the birth of the middle colic artery.

7. Treatment: Of the 144 patients in whom the treatment received was registered, $94(65.27 \%)$ received medical treatment and of these, 59 patients (62.77\%) presented a satisfactory response. One 
62-year-old male patient, with the diagnosis of well-differentiated gastric adenocarcinoma classified as Borrmann II, died for bronchoaspiration with sepsis of respiratory origin, while waiting for a laparoscopic approach to gastric cancer and Wilkie syndrome. Of the 84 patients who required surgical treatment, 50 patients $(59.52 \%)$ required it upon admission, and 34 patients (40.48\%) after receiving medical treatment with an unfavorable response. Table IX shows the surgical procedures performed. Laterolateral duodenojejunostomy alone or in combination with other surgical procedures was the surgical intervention most used and was performed in 59 cases (70.24\%).

8. Postoperative results, complications, and mortality: Of the 84 patients who received surgical treatment, 79 cases $(94.05 \%)$ had satisfactory results, there were four deaths (4.76\%) and one case $(1.19 \%)$ did not report results. Intra and postoperative complications occurred in seven patients and are shown in Table X.

9. The causes of death are shown in Table XI.

TABLE IX

SURGICAL PROCEDURES IN WILKIE'S SYNDROME.

\begin{tabular}{lcc}
\hline Surgical procedures & $\mathrm{N}^{0}$ of Cases & Percentaje \\
\hline $\begin{array}{l}\text { A. Duodenal derotation (1) } \\
\text { B.1. Treitz ligament section with duodenal descent (Strong technique) }\end{array}$ & 2 & $2.38 \%$ \\
as a unique surgical procedure (2) & 11 & $13.10 \%$
\end{tabular}

B.2. Treitz ligament section with duodenal descent (Strong technique) combined with another surgical procedure in an only surgical intervention

with laterolateral duodenojejunostomy

with superior mesenteric vessel reimplantation in the infrarenal aorta

3. Enteric bypass by

3.1. Gastrojejunals anastomosis

gastrojejunostomy due to significant gastric dilatation

$\begin{array}{cc}3 & 3.57 \% \\ 1 & 1.19 \% \\ 1 & 1.19 \% \\ & \\ 47 & 55.95 \% \\ 3 & 3.57 \% \\ 1 & 1.19 \% \\ 2 & 2.38 \% \\ & \\ 1 & 1.19 \% \\ 1 & 1.19 \%\end{array}$

3.2. Duodenoduodenostomy $1.19 \%$

3.3. Duodenojejunostomy as a unique surgical procedure

laterolateral duodenojejunostomy

$5.95 \%$

Roux-en-Y duodenojejunostomy

Duodenojejunostomy ahead of the superior mesenteric vessels with segmental resection of the duodenum

4. Total gastrectomy due to gastric necrosis

jejunostomy for enteral feeding

$1.19 \%$

(1) one case presented perforated ulcer at the level of the horizontal part of the duodenum that required resection of third and fourth part of the duodenum and terminoterminal anastomosis of the second part of the duodenum tojejunum. (2) two cases required a second intervention (laterolateral duodenojejunostomy) in one accompanied by a gastrectomy partial. 
TABLE $\mathrm{X}$

SURGICAL COMPLICATIONS IN WILKIE'S SYNDROME.

\begin{tabular}{|c|c|c|}
\hline Surgical complications & $\mathrm{N}^{\circ}$ of Cases & Percentaje \\
\hline 1. Need for surgical reinterventions & 5 & $71.42 \%$ \\
\hline Obstruction of the efferent loop by adhesions & 1 & \\
\hline Anastomosis leak & 1 & \\
\hline $\begin{array}{l}\text { A patient undergoing duodenal derotation that required two } \\
\text { reoperations: one by a bowel obstruction by adhesions, and another } \\
\text { by an ulcer perforated in the horizontal part of the duodenum that } \\
\text { required resection of the horizontal and ascended parts of the } \\
\text { duodenum with a terminoterminal duodenumjejunal anastomosis }\end{array}$ & 1 & \\
\hline Unsuceessful response to Strong's technique & 2 & \\
\hline 2. Pancreatic injury with fistula that responded to medical treatment & 1 & $14.29 \%$ \\
\hline $\begin{array}{l}\text { 3. Postoperative shock in a patient with large colon tumor that it pulled } \\
\text { and tensed the transverse mesocolon causing a duodenal compression }\end{array}$ & 1 & $14.29 \%$ \\
\hline
\end{tabular}

TABLE XI

CAUSES OF DEATH IN WILKIE'S SYNDROME.

\begin{tabular}{|c|c|c|}
\hline Causes of death & $\mathrm{N}^{\mathrm{o}}$ of Cases & Percentaje \\
\hline Cardiovascular complications in a female patient of 83 years & 1 & $16.67 \%$ \\
\hline $\begin{array}{l}\text { Multiple organ dysfunction syndrome three months after the operation in } \\
\text { a 56-year-old male patient with a history of hypertension, alcoholism and } \\
\text { chronic renal failure with aortic stent due to aneurysm }\end{array}$ & 1 & $16.67 \%$ \\
\hline $\begin{array}{l}\text { Respiratory symptoms five days after the operation in a } 19 \text {-year-old female } \\
\text { patient with a history of repetitive episodes of lung infection; hepatitis at } \\
\text { age 16; chickenpox in childhood; disseminated herpes simplex; autoimmune } \\
\text { hemolytic anemia and bronchiectasis }\end{array}$ & 1 & $16.67 \%$ \\
\hline $\begin{array}{l}\text { Postoperative shock in a } 77 \text {-year-old female patient with colon cancer when } \\
\text { resecting a tumor. The tumor pulled and tensed the transverse mesocolon } \\
\text { causing the duodenal compression }\end{array}$ & 1 & $16.67 \%$ \\
\hline $\begin{array}{l}\text { Bronchoaspiration with sepsis of respiratory origin in } 62 \text {-year-old male } \\
\text { patient with the diagnosis of well-differentiated gastric adenocarcinoma } \\
\text { classified as Borrmann III who was waiting for a laparoscopic approach to } \\
\text { gastric cancer and Wilkie syndrome }\end{array}$ & 1 & $16.67 \%$ \\
\hline $\begin{array}{l}\text { Rupture of an aortic aneurysm before being able to receive treatment in a } \\
66 \text {-year-old male patient }\end{array}$ & 1 & $16.67 \%$ \\
\hline
\end{tabular}

\section{DISCUSSION}

Wilkie syndrome or vascular compression of the duodenum is the constriction of the horizontal part of the duodenum by the root of the mesentery with partial or total duodenal obstruction. It is a rare and little known entity with an incidence between
$0.0024 \%$ and $0.53 \%$ (111), not included in the initial diagnostic possibilities, which delays the diagnosis (38) and treatment.

Its embryological and anatomical bases are well known $(111,112)$ : in humans, the superior mesenteric artery under normal conditions arises from the abdominal aorta at the level of the first lumbar vertebra at an 
angle that averages 42.4 degrees, with a wide range of variation from 18 to 70 degrees.

The extrinsic compression of the duodenum by the superior mesenteric artery occurs when the aortomesenteric angle decreases to values between 1 to 40 degrees with an average of 15.2 degrees (Fig. 3 ). The left renal vein and the uncinate process of the pancreas, located over the horizontal part of the duodenum, occupy the narrowest part of the aortomesenteric angle (Fig. 3). When the amplitude of the angle decreases, the left renal vein is pressed by the superior mesenteric artery, causing the nutcracker syndrome, which can occur alone (113) or in combination with the vascular compression syndrome of the duodenum $(105,114)$.

In the etiopathogenesis of this disease are distinguished predisposing and precipitating factors. The predisposing factors that contribute to the development of the compression of the duodenum by the superior mesenteric artery are $(111,115)$ : 1 .- The crossing of the horizontal part of the duodenum at the level of the fourth lumbar vertebra where the lumbar curvature reaches its most anterior position and is more pronounced. Under normal conditions, the horizontal part of the duodenum crosses the abdomen at the level of the third lumbar vertebra; occasionally, in women, the crossing is at the level of the fourth lumbar vertebra. 2.- exaggerated lumbar lordosis, or orthopedic or surgical procedures on the spine: normally, the aortomesenteric distance is from 10 to $28 \mathrm{~mm}$ and an exaǵgerated lumbar lordosis decreases it to 2 to $8 \mathrm{~mm}$. 3.- A shortened or hypertrophied of the suspensory muscle of the duodenum causes an upward movement of the duodenum at the angle between the superior mesenteric artery and the aorta. 4.- An abnormally low origin of the superior mesenteric artery. The precipitating factors are the significant weight loss or rapid growth without weight gain $(8,115)$ associated with an extensive loss of retroperitoneal and mesenteric fat that contribute to a decrease in the aortomesenteric angle and distance (8).

We found a predominance of the female sex over the male in a proportion of 2.57 , and the $50 \%$ of cases occurred in patients under 20 years of age, with the highest incidence in schoolchildren and adolescents, as it has been reported in the literature (111). The age range was from one day of life to 83 years of age, with an average of 26.093 years. Medical-surgical background and associated pathologies were present in 53 patients, with weight loss being present in 24 patients (45.28\%) (Table I) and anatomical causes that decreased aortomesenteric distance in 17 patients (32.07\%) (Table II).
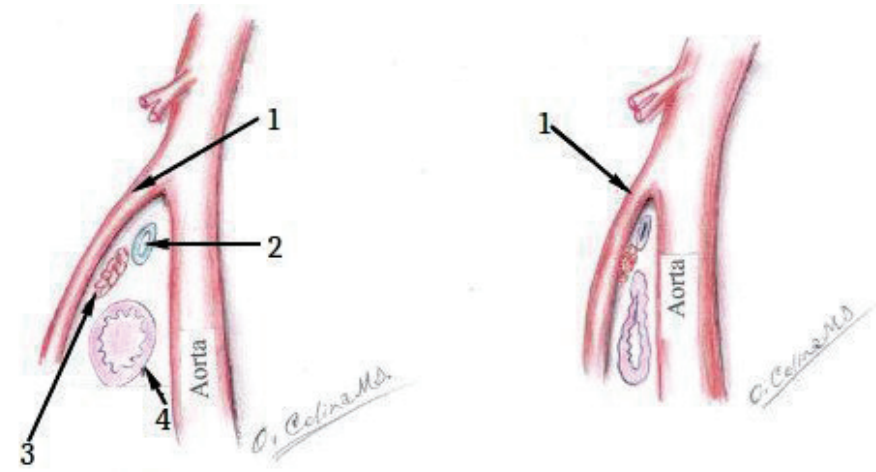

(1) superior mesenteric artery

(2) left renal vein

(3) uncinate process of the pancreas

(4) horizontal part of the duodenum

Fig. 3. Shows in the left side a normal angle aortomesenteric, and in the right side the constriction of the horizontal part of the duodenum by a decrease of the angle aortomesenteric. 
The clinical manifestations of this syndrome are abdominal pain, vomiting, weight loss (Table III), and sometimes, abdominal distention. The disease has two forms of presenting: acute, with signs of high small bowel obstruction (115-117), and chronic, with an insidious medical history of intermittent abdominal pain associated with vomiting, early satiety, and anorexia, many times for many years. In the chronic presentation, the symptoms are less specific and compatible with those of peptic ulcer disease, pancreatitis, biliary colic, and patients who are misdiagnosed and mistreated for many years, $(116,118)$ delaying diagnosis and proper treatment. In our analysis, we could compile the time of apparition of symptoms in 85 cases that ranged from 12 hours to 27 years. The disease manifested in an acute form in 14 cases (16.47\%) (in hours in one case and days in 13 cases) and in a chronic form in 71 cases (in months in 39 cases and years in 32 cases) (83.53\%). In our review, the most frequent symptoms were abdominal pain, vomiting, and weight loss. The abdominal distention, when it was present was a sign of gastric dilation $(79,81,100,119,120)$ and could be complicated with gastric necrosis $(81,100)$.

To make the diagnosis is necessary a high index of clinical suspicion and the meticulous evaluation of the radiological studies.

The acute presentation form manifests with signs of high partial obstruction of the small intestine. Simple X-ray of abdomen shows a gastric air bubble with few amounts of gas in the intestine distal to the site of obstruction $(5,7,66)$ See Fig. 4 . In the chronic presentation form, the symptoms often do not have the intensity that in the acute presentation form, the vomiting may not have bile, and the clinical picture can be confused with anorexia nervosa and bulimia delaying the diagnosis by months and years.

The upper gastrointestinal tract radiography shows (66): 1.- gastroduodenal dilatation with delay in contrast transit through the gastroduodenal region, accom- panied or not by gastroduodenal dilation, and fight sign of the stomach. Under normal conditions, the descending part of the duodenum empties the barium so quickly, that it is difficult to get a radiograph that shows this part of the duodenum well-distended; while in patients with vascular compression of the duodenum, the descending part of the duodenum remains distended (7); 2.- the narrowing of the horizontal part of the duodenum, as a vertical abrupt cut-off over or to the right of the spine and 3.- few amounts of contrast and gas, in the intestine distal to the site of obstruction; 4 .- the relief of obstruction with postural changes $(121,122)$.

The computed tomography as a diagnostic study replaced the hypotonic duodenography and the aortic and superior mes-

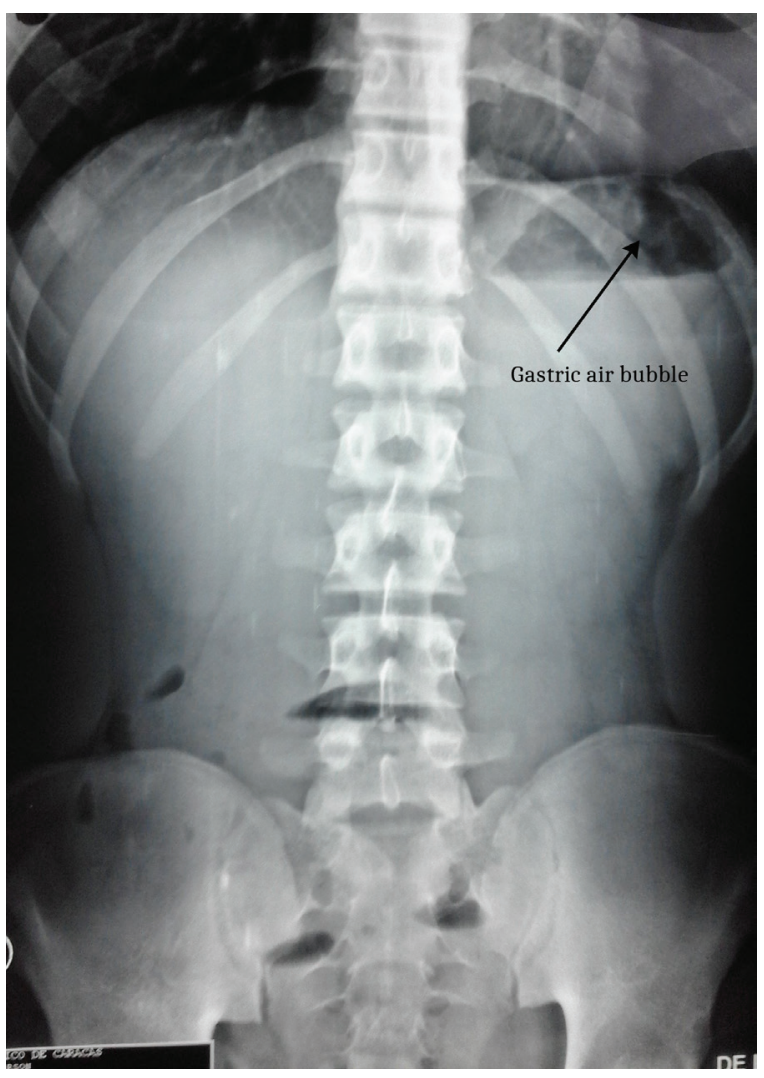

Fig. 4. Shows a Simple X-ray of abdomen standing where we can see a gastric air bubble with few amounts of gas in the intestine distal to the site of obstruction, a characteristic image of a high partial obstruction of the small intestine. 
enteric artery angiography, because it is: 1 . a fast, reliable, non-invasive method, 2 . shows the exact anatomic position of the duodenum in the aortomesenteric angle, 3 . allows to calculate the values of the aortomesenteric angle and the distance aortomesenteric, and 4. excludes other causes of obstruction $(111,122)$.

In the papers reviewed (121-128), the normal value of the aortomesenteric angle varied between $28^{\circ}$ to $65^{\circ}$ and the of the aortomesenteric distance between 10 and 34 $\mathrm{mm}$. The values of the aortomesenteric angle and distance are considered abnormal when these are less than $22^{\circ}$ to $25^{\circ}$ and of 8 to 10 $\mathrm{mm}$ respectively $(66,121-128)$. In our review, the value of the aortomesenteric angle varied from $6^{\circ}$ to $40^{\circ}$ with an average of $16.1^{\circ}$, and the of the aortomesenteric distance varied from 0.53 to $10.5 \mathrm{~mm}$ with an average of 4.38 $\mathrm{mm}$; and these values coincide with those reported in the literature $(111,112)$.

The upper gastrointestinal tract endoscopy allows: to show the presence of the narrowing of the horizontal part of the duodenum sometimes reported as pulsatile compression, accompanied or not by gastroduodenal dilation, also rule out associated pathologies such as bezoars (97) and peptic ulcers $(107,129-131)$ and, allows the placement of nasojejunal tubes beyond the obstruction site to provide enteral nutrition support (118). When it is performed with curvilinear array endoscopy ultrasound, the value of the aortomesenteric angle (132) can be determined.

In the differential diagnosis, it is convenient to keep in mind the diagnosis of inverse duodenum, which is a duodenal anomaly that has also been associated with obstructive symptoms and that simulate the clinical manifestations of Wilkie's syndrome and its upper gastrointestinal tract radiography has been interpreted as compatible with the superior mesenteric artery syndrome (133-135).

In the absence of pathological conditions that need immediate surgical explora- tion, for example, an aneurysm, the treatment of the Wilkie's syndrome is initially medical and consists of gastric decompression, correction and maintenance of the hydro-electrolytic balance, antibiotic therapy and enteral nutritional support through of nasogastric (110) or nasojejunal tube (136-137), which causes weight gain with an increase in the peripheral fat to the superior mesenteric artery that augmentation the angle and the distance between the superior mesenteric artery and the aorta, with the disappearance of the symptomatology. Surgical treatment is necessary when medical treatment fails, or when there are clinical manifestations of intestinal obstruction (51, 66,118,137-139).

There are three types of surgical interventions:

1. Enteric bypass procedure. Of the three surgical procedures included in this section, the laterolateral duodenojejunostomy, proposed by Bloodgood (140), first performed suceessfully by Stavely (141) and popularized by Wilkie (2-3), is the most frequently performed surgical procedure with satisfactory results and with a very low complication rate. Gastrojejunostomy has been performed when there is a significant gastric dilation but it is not recommended because the duodenal content before the site of obstruction must pass to the stomach to drain to the jejunum $(137,139)$. Sometimes, during the surgical intervention, the inframesocolic duodenum does not look dilated and the diagnosis of vascular compression of the duodenum could be missed (4). There is an intraoperative maneuver that consists of the injection of 150 to $300 \mathrm{ce}$ of air through a nasogastric tube, observing after the air injection, dilatation of the duodenum from 4 to $5 \mathrm{~cm}$, when there is a vascular compression of the duodenum (139).

2. Section of the suspensory muscle of the duodenum with the descent of 
the duodenal-jejunal angle: In 1958, Strong described one case of arteriomesenteric duodenal obstruction in which he practiced the section of the suspensory muscle of the duodenum with surgical mobilization of the ascending part of the duodenum and relocation of the duodenojejunal angle from the level of the second to the third lumbar vertebral body, with complete remission of the symptomatology (142). In our analysis, we found this surgical technique was performed as an only surgical procedure in 11 patients with a success rate of $81.82 \%$. Two of these cases required a second intervention (laterolateral duodenojejunostomy). In eleven cases, it was performed with another surgical procedure in a single surgical intervention; in 10 eases with duodenojejunostomy and in one case with reimplant of the superior mesenteric artery.

3. Duodenal derotation: described by Louw and recommended by Wayne and Burrington for the treatment of children with this pathology (6-8), in our analysis, it was only performed in 2 cases and one of them required a second intervention by had perforated ulcer in the horizontal part of the duodenum that required resection of horizontal and ascending part of the duodenum and terminoterminal anastomosis of the descending part of the duodenum to the jejunum. The duodenal derotation also is known as Ladd's procedure (143-144), consisting of lysing the suspensory muscle of the duodenum with of mobilizing the entire duodenum and the proximal jejune. The opening at the root of the mesentery is enlarged to at least 10 $\mathrm{cm}$ in length, and the entire jejunum is passed to the right through this opening. The entire duodenum and proximal part of the jejunum now lie in the right paravertebral gutter, much as they do after the Ladd procedure for intestinal malrotation. The mesentery should be left attached to the retroperitoneum in the region of the ileocecal valve, and the lateral attachments of the ascending colon should also be preserved to prevent midgut volvulus (8). It has been practiced successfully and has the advantage that it does not need the use of anastomosis (4-8,143-147).

When analyzing the medical treatment vs. surgical treatment of 150 patients, six patients were excluded: five in whom the treatment received was not specified, and one that died before being able to receive the treatment. Of the remaining 144 patients, 94 received medical treatment, with a satisfactory response in $62.77 \%$ of cases, and one death for bronchoaspiration with sepsis of respiratory origin, in a 62-year-old male patient with the diagnosis of well-differentiated gastric adenocarcinoma, classified as Borrmann III, who expected by a therapeutic laparoscopic approach to gastric cancer and Wilkie syndrome. Of the 84 patients who required surgical treatment, $59.52 \%$ of the cases required it upon admission and $40.48 \%$ had received medical treatment with an unfavorable response. Intra or postoperative complications occurred in seven cases (8.235\%), and of these, five cases (5.88\%) required surgical reintervention. The causes of surgical reinterventions are shown in Table X. Once the surgical complications were overcome, all patients undergoing surgical treatment responded satisfactorily, and the symptoms disappeared.

Causes of death. As can be seen in Table XI, the causes of death found are related to pathologies concomitant with the duodenal vascular compression syndrome (aneurysms, malignant tumors, senility, immunological alterations).

From this review, we can conclude that vascular compression of the duodenum is a pathological entity that results from the decrease in angle and distance aortomesenteric, whose highest incidence is in patients under 20 years of age, predominating in schoolchildren and adoleseents. This syndrome has two 
ways of manifesting clinically: 1 . an acute clinic form, with a high partial intestinal obstruction; and 2. a chronic, insidious presentation, which is often confused with anorexia nervosa. It is diagnosed by upper gastrointestinal tract radiography, computed tomography, and upper gastrointestinal tract endoscopy. The diagnostic radiological criteria are: 1 . abrupt vertical and oblique compression of the mucosal folds, produced by the constriction of the horizontal part of the duodenum by the superior mesenteric artery; 2 . delay in contrast transit through the gastroduodenal region; 3. dilatation of the first and second portions of the duodenum, with or without gastric dilatation; 4. an antiperistaltic flow of barium proximal to the obstruction producing to-and-fro movements; 5. relief of obstruction when the patient is placed in a position that diminishes the drag of the small bowel mesentery (the left later decubitus, prone, or the knee-chest position) (148). The tomographic criteria are: 1 . abrupt obstruction in the third portion of the duodenum, with active peristalsis, 2 . an aortomesenteric angle less than $25^{\circ}$ and an aortomesenteric equal to or less than $8 \mathrm{~mm} 3$. high fixation of the duodenum by the suspensory muscle of the duodenum or anatomical variants of the superior mesenteric artery $(46,149)$. The upper gastrointestinal tract endoscopy allows: 1. to show the presence of the narrowing of the horizontal part of the duodenum, sometimes reported as pulsatile compression, accompanied or not by gastroduodenal dilation, 2. rule out associated pathologies such as bezoars and peptic ulcers and, 3 . the placement of nasojejunal tubes beyond the obstruction site for providing enteral nutrition support.

The treatment is initially medical (110) and consists of gastric decompression, fluid electrolytes imbalance correction, antibiotic therapy, and nutritional support either through total parenteral nutrition or nasojejunal tube feeding $(46,150)$. The nutritional support is aimed at the gain of weight, to the restoration of retroperitoneal fat, with increase in retroperitoneal and mesenteric fat that contributes to increasing the values of the aortomesenteric angle and distance. Posturing maneuvers during meals and prokinetic medications may be helpful in some patients with nutritional support. If medical treatment fails there are three surgical treatment options (137): 1- Section of the suspensory muscle of the duodenum with the descent of the duodenal-jejunal angle; 2. laterolateral duodenojejunostomy, and 3. duodenal derotation. Of these, the most practiced is the laterolateral duodenojejunostomy with satisfactory results.

\section{ACKNOWLEDGMENTS}

We would like to thank the staff of the "Dr. Francisco Baquero González" Library for the search for medical research papers; Drs. Hilda Martorelli and Jorge Barba Flores, who reviewed the paper and for its translation into the English language.

\section{REFERENCES}

1. Bermanski P, Golden Richard L, Ricea Richard J. Superior mesenteric artery syndrome complicated by pancreatitis. A case presentation and historical background. Vase Surg 1995; 29(3):217-223. Available from: http://journals.sagepub.com/doi/pdf $/ 10.1177 / 153857449502900308$.

2. Wilkie DPD. Chronic duodenal ileus. Br J Surǵ 1921;9:204-214. https://doi. org/10.1002/bjs.1800093405.

3. Wilkie DPD. Chronic duodenal ileus. Am J Med Sci 1927;173:643-649.

4. Wayne ER, Burrington JD. Extrinsic duodenal obstruction in children. Surg Gynecol Obstet. 1973;136(1):87-91.

5. Wayne ER, Burrington JD. Management of 97 children with duodenal obstruction. Arch Surg 1973; 107(6):857-860. Available from: https://Doi:10.1001/archsurg. 1973.01350240027009.

6. Wayne ER, Burrington JD. Duodenal Obstruction by the superior mesenteric artery in children. Surg 1972;72(5):782-768.

7. Burrington JD, Wayne ER. Obstruction of the duodenum by the superior mesenteric 
artery - Does it exist in children? J Pediatr Surg 1974;9(5):733-741. Doi: https://doi. org /10.1016/0022-3468(74)90112-2.

8. Burrington JD. Superior mesenteric artery syndrome in children. Am J Dis Child 1976; 130(12):1367-1370. Doi: 10.1001/archpedi.1976.02120130073015.

9. Rodríguez A, Romero Vidomlansky SI, Ferrarotti C, Larrañaga N, Gallo JC, Kozima S. Síndrome de la arteria mesentérica superior. Presentación de un caso. Rev Argent Radiol 2014;78(2):96-98. Https://doi. org/10.1016/j.rard.2014.06.007.

10. Naveiro JJ, Jimenez A, Kury M, Abate M, Amor H. Síndrome de compresión vascular del duodeno. Rev Arǵent Cir 1991;61:146149.

11. Fiorini S, Sáenz Tejeira MM, Tennina C, Tomezzoli S, Requejo N. Síndrome de la arteria mesentérica superior (síndrome de Wilkie). Caso clínico. Arch Argent Pediatr 2008;106(6):533-551. https://www. sap.orǵ.ar/docs/archivos/2008/arch08_6/ v106n6a15.pdf

12. Arrieta Yánez L, Aycardi Valverde F, Quintana C. Síndrome de la arteria mesentérica superior en adolescente de 15 años de edad. Reporte de un caso. Rev Pediatr Elizalde 2015;6(1-2):31-33. Available from: https:// apelizalde.org/revistas/2015-1-2-ARTICULOS/RE_2015_1-2_RC_4.pdf

13. Manfrin L, Serigni A. Adolescente con dolor abdominal y vómitos. Med Infant 2013;20(1):58-61. Available from: http:// www.medicinainfantil.org.ar/imaǵes/stories/volumen/2013/xx_1_058.pdf

14. Herbella FAM, Varela CE, Miranda Jr. F, Del Grande JC, Beaton HL. Superior mesenteric artery syndrome and aortic aneurism. Arq Bras Cir Dig 2005;18(1):25-27.

15. Barchi LC, Alves AM, Jacob CE, Caldas Bresciani CJ, Yagoi OK, Noĝueira TG, Cecconello I, Zilberstein B. Favorable minimal invasive surgery in the treatment of superior mesenteric artery syndrome: Case report. Int J Surǵ Case Rep 2016;29:223-226. https://doi. org/10.1016/j.ijscr.2016.09. 016.

16. Takano C, Oliveira F, Okawa M. Síndrome do pincamento aorto-mesenterico - Relato de caso. Rev Med Paraná 2004;62(1):24-26.

17. Barros DH de, Argouello MEF, Hoyo MBD, Ramos SRTS. Síndrome da artéria mesen- térica superior: relato de um caso. Pediatria (São Paulo) 2003;25(3):134-137.

18. Lima HS, Maia AM, Castro Neto AKP de. Síndrome da artéria mesentérica superior. Rev Col Bras Cir 2000;27(2):128-130.

19. Alvarez GC, Dal Bosco MH, Streher LA, Alvarez SJ, Ritzel RA. Síndrome da artéria mesentérica superior. Rev Col Bras Cir 1994;21(4):225-226.

20. Cavichini QN, Tinoco ECA, Brum AV, Anderson PAV, Gomes LR. Obstruçäo duodenal por compressäo vascular: síndrome da artéria mesentérica superior. Rev Col Bras Cir 1994;21(4):229-232.

21. Almeida Jr. $\mathbf{N}$ de. Estase duodenal crônica por oclusäo aortomesentérica Rev Bras Med 1987;44(4):94-97.

22. França Neto PR, Paiva RdeA, Lacerda Filho A, Queiroz FL de, Noronha T. Superior mesenteric artery compression syndrome - case report. J Coloproctol (Rio J.) 2011;31(4), 401-404. Doi: 10.1590/s22379363201100040001.

23. Matheus Claudio de Oliveira, Waisberg J, Zewew MH de Toledo, Godoy AC de. Syndrome of duodenal compression by the mesenteric artery following restorative proctocolectomy: a case report and review of literature. Sao Paulo Med J 2005;123(3):151-153. Available from: http://www.scielo.br/pdf/spmj/v123n3/ a13v123n3.pdf.

24. Cesconetto DM, Mattosinho TJ, Gestic MA, Chaim EA. Superior mesenteric artery syndrome: case report. GED 2012;31(4):138141. Available from: http://files.bvs.br/ upload/S/0101-7772/2012/v31n4/a3929. pdf.

25. Martín Torres OJ, Soares Costa V da C, Noleto Araujo RA, Lima e Lima CN, Costa de Castro IT. Síndrome da artéria mesentérica superior: relado de caso. GED 2013;32(2):50-52.

26. Zorrón R, Milcent M, Contreras M, Lukashok H, Marquez R, Madureira Filho D. Laparoscopic repair of superior mesenteric artery syndrome: sutured Handsewn duodenojejunostomy technique. Rev Bras Video Cir 2003;1(3):87-91. https://www.sobracil.org. br/revista/rv010103/rbve010103_087.pdf.

27. De Oliveira Martins RG. Síndrome de Wilkie secundária a volumoso aneurisma da 
aorta abdominal: relato de caso. Available from: http://iradtelerradiologia.com.br/ wp-content/uploads/2017/12/RELATODE-CASO-SAMS.pdf.

28. Pastén González A, Muñoz Araneda A, Peirano Bastías A, Rojas Castro S, Henríquez Alessandrini V. Síndrome de la arteria mesentérica superior. Presentación de un caso y revisión de la literatura. Cir Pediatr 2016;29:180-183. Available from: https://www.secipe.org/coldata/upload/revista/2016_29-4_180_183.pdf

29. Ríos M G, Thumler U J, Toro A C. Síndrome de la arteria mesentérica superior. Presentación de dos casos. Rev Chil Pediatr 1986;57(4):355-358. Available from: https://scielo.conicyt.cl/pdf/rep/v57n4/ art10.pdf.

30. Ibarra-I FJ, Arriagada-M D. Síndrome de la arteria mesentérica superior: caso clínico y revisión. Bol Esc Med UC de Chile 2006;31(1):42-46 Available from: http://publicacionesmedicina.uc.cl/Boletin/20061/SindromeArteria.pdf

31. Tapia-V A, Sharp-P A, Llanos-L O, RahmerO A, Zúñiga Díaz A. Síndrome de compresión vascular del duodeno. Comunicación de 2 casos. Rev Med Chile 1993; 121: 425 429.

32. Castaño Llano R, Chams Anturi A, Arango Vargas P, García Valencia Á. Síndrome de la arteria mesentérica superior o síndrome de Wilkie. Rev Colomb Gastroenterol 2009;24(2):200-209. Available from: http://www.scielo.org.co/pdf/reg/v24n2/ v24n2a14.pdf.

33. Jiménez-Castro L, Aguirre HD, PosadaLópez AF. Síndrome de arteria mesentérica superior secundario a quemadura severa. CES Medicina 2014;28(1):139-146. Available from: http://www.scielo.org.co/pdf/ cesm/v28n1/v28n1a12.pdf

34. Vásquez-Arango JN, Durán-Meléndez MA, Vásquez-Maya C. Tratamiento mínimamente invasivo del síndrome de Wilkie. Rev Colomb Cir 2018; 33:299-306. Available from: http://www.revistacirugia. org/media/k2/attachments/sindromede-Wilkie-vasquez.pdf. https://doi.org/10. 30944/20117582.75.

35. Poblete-Otero F, Álvarez-Pertuz H, AranaSáenz A. Síndrome de Wilkie . Acta Méd Cos- tarric 2015;57(3):145-148. Available from: http://actamedica.medicos.cr/index.php/ Acta_Medica/article/download/893/811

36. Delgado Alonso A, Morales Díaz I, Pita Armenteros L. Síndrome de la arteria mesentérica superior: presentación de un caso y revisión de la literatura. Rev Cubana Cir 2008;47(2) Available from: http://scielo. sld.cu/pdf/cir/v47n2/cir08208.pdf.

37. Larrea Fabra ME. Compresión vascular del duodeno: presentación del caso. Rev Cubana Cir 1986;25(1):35-40.

38. Molina Proaño GA, Cobo Andrade MM, Guadalupe Rodrígouez RA, Gálvez Salazar PF, Cadena Aguirre DP, González Poma GV, Gutierrez Granja BM. Wilkie's syndrome, a missed opportunity. J Surg Case Rep 2018;9:1-3. Doi: 10.1093/jscr/rjy246.

39. Castillo León J, Pacheco Barzallo F, Ordoñez M del Cisne, Pacheco Granda F. Síndrome de Wilkie. Rev Cir 2017;14(1):49-54. Available from: http://www.scǵp.org/revista-cirujano/pdf/2017-REVISTA-CIRUJANO. pdf.

40. Alvarado-García R, Ponce-Rosas A, GarcíaSánchez D, Gallego-Grijalva JE. Compresión vascular del duodeno en un neonato. Acta Pediatr Méx 2007;28(2):69-73. Available from: https://www.medigraphic.com/ pdfs/actpedmex/apm-2007/apm072e.pdf.

41. Calderon Elvir C, Tapia Garibay JI, Ismael Cuzmar M. Síndrome de la arteria mesentérica superior: un diaǵnóstico infrecuente en el cual se debe pensar. Acta Pediatr Méx 1994;15(1):37-40.

42. García Álvarez J, Pérez Islas A, Sánchez Conde RM, Luna Ortíz K. Síndrome de la arteria mesentérica superior. Informe de una paciente. Cir Gen 2000;22(4):347-350. Available from: https://www.medigraphic. com/pdfs/cirǵen/cg-2000/cg004h.pdf.

43. García-Frade-Ruiz LF, Mundo-Gallardo LF, Solís-Ayala E. Síndrome de Wilkie. Med Int Méx 2017;33(2):254-258. Available from: http://www.scielo.org.mx/pdf/mim/ v33n2/0186-4866-mim-33-02-00254.pdf.

44. Garteiz Martínez D, Carbó Romano R, Bravo Torreblanca C, López Acosta ME, Vega Rivera F, Weber Sánchez A. Abordaje laparoscópico para la liberación del liǵamento de Treitz en paciente con síndrome de arteria mesentérica superior. Rev Méx 
Cir Endoscop 2009;10(1):49-53. Available from: https://www.medigraphic.com/pdfs/ endoseo/ce-2009/ce091j.pdf.

45. González Camarena V. Síndrome de compresión duodenal por los vasos mesentéricos. Cir Cir 1984;52(3):203-206.

46. González Hermosillo-Cornejo D, Díaz Girón-Gidi A, Vélez-Pérez FM, LemusRamírez RI, Andrade Martínez-Garza P. Síndrome de Wilkie. Reporte de un caso. Cir Cir 2015; 85(1):54-59. Https://doi. org/10.1016/j.circir.2015.08.009.

47. González Mondragón MB, Granados Navas FJ, Herrera Garcia W. Síndrome de la arteria mesentérica superior en un paciente con tuberculosis abdominal. Acta Pediatric Méx 2010;31(5):244-247. Available from: http://www.redalyc.org/pdf/ 4236/423640325011.pdf.

48. Loera-Torres MA, García-Núñez LM, Cabello-Pasini R, Morales Arias S, Núñez Cantú O, Rivera-Cruz JM. Síndrome de Wilkie: Reporte de dos easos. Rev Sanid Milit Méx. 2010;64(1):41-46. Available from: https:// www.medigraphic.com/pdfs/sanmil/sm2010/sm101g.pdf.

49. Navarrete-Arellano M, Soto-Fernández AE. Síndrome de arteria mesentérica superior: Dos casos clínicos en pacientes pediátricos. Rev Méx Cir Pediatr 2009;16(3):119125. Available from: https://www.medigraphic.com/pdfs/revmexcirped/mep-2009/ mep093c.pdf.

50. Ochoa-Nava R, Guadarrama-Vallejo AC, García-Carrizosa S, Herrera-Víctor FJ. Síndrome de la arteria mesentérica superior: una causa inusual de obstrucción intestinal incompleta en un paciente pediátrico. Rev Méx Pediatr 2017;84(2):61-65. Available from: https://www.medigraphic.com/pdfs/ pediat/sp-2017/sp172d.pdf.

51. Osegueda de Rodríguez EJ, HernándezVillegas AC, Serralde-Zúñiga AE, ReyesRamírez ALdelC. The two sides of superior mesenteric artery syndrome treatment: conservative or surǵical manaǵement? Nutr Hosp 2017;34(4):997-1000. Available from: http://scielo.isciii.es/pdf/nh/v34n4/33_ nota.pdf.

52. Ovalle-Chao C, Hinojosa-Martinez LM, Gutierrez-Castillo A, Velazco-De La Garza JH, Flores-Villalba E, Diaz-Elizondo JA,
Garza-Serna U. Acute-onset of superior mesenteric artery syndrome following surgical correction of scoliosis: Case report and review of literature. J Pediatr Surg Case Rep 19 (2017) 31e33. https://doi. org/10.1016/j.epsc.2017.02.008.

53. Sánchez-Lozada R, Acosta-Rosero AV, Balas-Salame C, Chapa-Azuela O, HurtadoLópez LM. Síndrome de la arteria mesentérica superior como causa de intolerancia parcial crónica a la alimentación oral. Reporte de un caso y revisión del tema. Rev Gastroenterol Méx 2002;67(1):38-42.

54. Suárez Gutiérrez R, Jiménez Urueta PS, Castañeda Ortiz RA, Sánchez Michaca VJ, García Galavís JL. Megagastria y megaduodeno asociado con síndrome de arteria mesentérica superior y síndrome de cascanueces. Rev Esp Méd Quir 2011;16(1):51-55. Available from: http://www.redalyc.org/service/redalye/ downloadPdf/473/47317815010/1.

55. Valdes $A$, Cárdenas $O$, Espinosa A, Villazón O, Valdes V. Superior mesenteric artery syndrome. J Am Coll Surg 2005;201(5):808. https://doi.org/10.1016/j.jamcollsurg. 2005.04.033.

56. Ruíz-Mar G, Cárdenas Serrano OE, Álvarez Correa LA, Morán Sierra OT, Sánchez Navarro López AL, Sánchez-Delgado, Pérez Escobedo SU. Manejo quirúrgíco de urǵencia en el síndrome de Wilkie. A propósito de un caso. Cir Gen 2018;40(4):279281. Available from: https://www.mediǵraphic.com/pdfs/cirgen/eǵ-2018/eg184j.pdf.

57. Loja Oropeza D, Alvizuri Escobedo J, Vilva Vazquez M, Sánchez Mercado M. Síndrome de Wilkie: Compresión vascular del duodeno. Rev Gastroenterol Perú 2002;22(3):248-252. Available from: http:// www.scielo.org.pe/scielo.php?pid=S1022$51292002000300009 \&$ script $=$ sei arttext.

58. Varela Vega M, Durán F, Larrosa G, Reyes S, Cabillón J, Simonet F. Síndrome de Wilkie: un caso de oclusión duodenal por pinza aortomesentérica. Salud Militar 2017;36(1):51-54.

59. Czarnevicz Canavesi D, Secondo G, Radio A, Odriozola M, Rossi I, Iacopino J. Oclusión duodenal por pinza aortomesentérica. Un nuevo caso clínico. Cir Uruguay 1994;64:225-227. 
60. Acosta-M B, Guachalla G, Martínez C, Felce S, Ledezma G. Compresión vascular del duodeno. GEN 1991;45(1):61-64.

61. Sánchez Ismayel A, Cohén D, D’Amelio C, Daly K, Sánchez R, Salas J. Síndrome de arteria mesenterica superior: causa inusual de obstruccion duodenal. Vitae 2007;32. Available from: http://vitae.ucv.ve/index_ pdf.php?module $=$ articulo_pdf\&n $=1136$.

62. Bandres D, Ortiz A, Dib Jr. J. Superior mesenteric artery syndrome. Gastrointest Endose 2008;68(1):152-156: https://doi. org/10.1016/j.gie.2007.09.033.

63. Mota M, Abusaid S, Muñoz C. Síndrome de Wilkie: a propósito de un caso. CIMEL. 2014;19(2):91-95. Available from: https:// www.cimel.felsocem.net/index.php/CIMEL/article/download/491/297.

64. Vassallo M, Marín J, Hernández Y, Chaparro ML, Malave H. Síndrome de la arteria mesentérica superior. Reporte de un caso y revisión de la literatura. Rev Fac Med 2010;33(2):159-163. Available from: http://190.169.30.98/ojs/index.php/rev_ fmed/article/download/4909/4720.

65. Trejo Padilla E. Cirugía del tubo digestivo en el niño. Tribuna Médica 1976;45(5):41-48.

66. Trejo Scorza E, Brito Arreaza EJ, Colina Cedeño OL, Lander Gonzalez BJ, Trejo Scorza CJ. Vascular compression of the duodenum or Wilkie's syndrome. Presentation of a case and review of world medical literature. Rev Cent Med 2019;58(148):4348. Available from: https://www.revistacentromedico.org/ediciones/2019/2/art-3/

67. Rosa-Jiménez F, Rodríguez González FJ, Puente Gutiérrez JJ, Muñoz Sánchez R, Adarraga Cansino MD, Zambrana García JJ. Compresión duodenal por la arteria mesentérica superior: análisis de 10 pacientes. Rev Esp Enferm Dig 2003;95(7):480-484.

68. Gutiérrez Junquera C, Gonzálvez Piñera J, Pérez Martínez A, Marco Macián A. Síndrome de arteria mesentérica superior: Una causa infrecuente de obstrucción duodenal en la infancia. An Esp Pediatr 1996;45:289290. http://www.aeped.es/sites/default/ files/anales/45-3-14.pdf.

69. Morán Penco JM, Cardenal Murillo J, De La Calle Pato U, Masjoan D. Un posible caso de origen congénito de síndrome de la arteria mesentérica superior (SAMS). Cir
Pediatr 2008;21:228-231. Available from: https://www.secipe.org/coldata/upload/revista/2008;21.228-31.pdf

70. Fernández López MT, López Otero MJ, Bardasco Alonso ML, Álvarez Vázquez P, Rivero Luis MT, López Barros G. Síndrome de Wilkie: a propósito de un caso. Nutr Hosp 2011;26(3):646-649. Available from: http://scielo.isciii.es/pdf/nh/v26n3/31_ caso_clinico_01.pdf.

71. Ruíz Padilla FJ, Mostazo Torres J, Vílchez Jaimez M. Significant gastric distension caused by superior mesenteric artery syndrome or Wilkie's syndrome. Gastroenterol Hepatol 2017;40:581-583. https://doi. org/10.1016/j.gastre.2017.08.002.

72. Beltrà Picó R, Hernández Castelló C, Sanchis Solera L, Guindos Rúa S, Mol A, Germani M. Laparoscopia en cirugía pediátrica. Utilidad en enfermedades poco frecuentes. Canar Pediátr 2013;37(3):172178. Available from: http://portal.septfe. com/wp-content/uploads/2013/12/20132.a.pdf

73. Castañeda Heredia A, Gálvez García C, Rivero Falero M, Abreu Yanes I, Martín Fumero L. Síndrome de arteria mesentérica superior en una niña de 11 años con escoliosis tratada con un corsé corrector. Canar Pediátr 2013;37(3): 179-181. Available from: http://portal.septfe.com/wp-content/uploads/2013/12/2013-2.b.pdf.

74. Farré R, Blanco JA, Isnard RM, Alastrue A, Castellví A. Pinça aortomesentèrica, síndrome de l'artèria mesentèrica superior $\mathrm{o}$ síndrome de Wilkie. A propòsit d'un cas. Pediatr Catalana 2008;68:205-207. Available from: http://webs.academia.cat/revistes elect/view_document.php?tpd $=2 \& \mathrm{i}=2127$.

75. Calero-García P, Jurado-Román M, MartínScortechini M, Flores-Garnica LM, Sagredo P, Valiente-Carrillo J. Duodenal vascular compression syndrome: Cause to be considered in cases of intestinal obstruction. Rev Esp Enferm Dig 2012;104(10):559-560.

76. Pérez-Flecha González M, Rioja Conde P, Caso Maestro Ó, García Aroz S, Marcacuzco Quinto AA, Bermello Meza CF, Pérez Torres JB, Jiménez Romero LC. Síndrome de arteria mesentérica superior como causa de dolor abdominal crónico. Cir Esp 2015;93 (Espec Congr):390. 
77. Velazquez Kennedy K, Yela R, Achalandabaso MdelM, Martín-Pérez E. Superior mesenteric artery syndrome: Diaǵnostic and therapeutic considerations. Rev Esp Enferm Dig 2013;105(4):236-238.

78. Sihuay-Diburgáa DJ, Accarino-Garaventa A, Vilaseca-Montplet J, Azpiroz-Vidaur F. Acute pancreatitis and superior mesenteric artery syndrome. Rev Esp Enferm Dig 2013;105(10):626-628.

79. Barquín-Yagüez J, Abadía-Barno P, GarcíaPérez JC. Superior mesenteric artery syndrome: an uncommon cause of intestinal obstruction. Rev Esp Enferm Dig 2017; 109(1):60.

80. Castillo Wisman MA, Alvarez Galán MdelC, Rodriguez-Bobada Aguirre R, Arenas Mosqueda J. Dolor abdominal recurrente psicológico o anatómico secundario a síndrome de Wilkie. Rev Clín Med Fam 2014;7(2):130-133. Available from: http:// www.revclinmedfam.com/PDFs/0e 74b7f78 409a4022a2c4c5a5ca3ee19.pdf.

81. Bázquez Lautre L, Soriano Gil P, Merck Navarro B, Vicente García F, Herrera Cabezón J, Lera Tricas JM. Necrosis gástrica por distensión aǵuda del estómaǵo y síndrome de la pinza mesentérica. Rev Esp Enferm Diǵest 1995;87(1):56-57.

82. Fuentes J, Sebastián JJ, Martín ML, Manero S, Uribarrena R. Técnicas de imaǵen en la pinza aorto-mesentérica. Rev Esp Enferm Dig 1997;89(12):934.

83. Molina Rodríguez JL, Martí Obiol R, López Mozo, F, Ortega Serrano J. Síndrome de la pinza aortomesentérica. Cir Esp 2012;90(1):53 http://dx.doi. org/10.1016/j.ciresp.2010.06.018.

84. Etxebarria Beitia E, Díez del Val I, Loureiro González C, González Serrano C, Bilbao Axpe JE. Duodenoyeyunostomía laparoscópica como tratamiento del síndrome de la arteria mesentérica superior. Cir Esp 2014;92(2):127-141. http://dx.doi. org/10.1016/j.ciresp.2013.06.020.

85. Martínez-Pérez A, Trullenque-Juan R, Santarrufina-Martínez S, ArmañanzasVillena E. Massive gastrointestinal pneumatosis in a patient with celiac disease and superior mesenteric artery syndrome. Rev Esp Enferm Dig 2015;107(11):709-710.

86. García Espinoza J, Martínez Matínez A, Tomás Muñoz P, Ruiz Carazo E. Superior mesenteric artery syndrome: a rare cause of intestinal obstruction due to the lack of fat. Sapd online 2017;40(4):193-195. Available from: https://www.sapd.es/revis$\mathrm{ta} / 2017 / 40 / 4 / 06 / \mathrm{pdf}$.

87. Aneiros Castro B, Cano Novillo I, García Vázquez A, Martín Alelu R, Gómez Fraile A. Wilkie's syndrome in monozygotic twins treated by 3-D laparoscopic duodenojejunostomy. Asian J Endosc Surg 2019;12(1):125127. Available from: https://onlinelibrary. wiley.com/doi/epdf/10.1111/ases.12489.

88. Valle Hernández E del, Goyanes Martínez A, Muñiz González J. Compresión vascular del duodeno. Rev Esp Enferm Dig 1984;65(1):41-48.

89. Oliva Fonte C, Fernández Rey CL, Pereda Rodríguez J, González Fernández AM. Wilkie's syndrome. Rev Esp Enferm Dig 2017;109(1):62-63.

90. Alsina Segúí E, Moreno Flores A, Llorens Salvador R. Síndrome de la arteria mesentérica superior en edad pediátrica: ¿Infrecuente o infradiaǵnosticado? Rev Esp Pediatr 2014;70(4):183-188. Available from: https://www.seinap.es/wp-content/uploads/Revista-de-Pediatria/2014/ REP\%2070-4.pdf\#page $=6$

91. Fernández Fernández L, Vicente Colomer JM, Vicente Guillén V, Luengo R. de Ledesma, L. Compresión vascular duodenal. Rev Esp Enferm Dig 1988;73(3):322-323.

92. Sánchez Blanco JM, Figueroa Andollo JM, Moreno Azcoita M, Sieira Pérez A, Moreno González E. Obstrucción duodenal aguda por pinzamiento aorto-mesentérico. Rev Esp Enferm Dig 1979;56(4):353-360.

93. Rodríguez Caraballo L, Carazo Palacios ME, Ibáñez Pradas V, Rodríguez Iǵlesias P. Wilkie syndrome: A differential diagnosis of abdominal pain. An Pediatr 2015;82(6):445-6. Available from: https://www.sciencedirect.com/ science/article/pii/S1695403314005694/ pdfft? m $5=\mathrm{d} 01 \mathrm{~b} 1007$ ad $520 \mathrm{caa}$ 17221 ede $53957508 \&$ pid=1 -s $2.0-\mathrm{S} 1$ 695403314005694-main.pdf.

94. Octavio de Toledo JM, Gómez Lorenzo F, Domínguez J, Cimadevila J, Bermúdez J, Fernández P. Comprensión vascular del duodeno relacionada con un corsé de yeso (cast syndrome) Rev Esp Enferm Diǵ 1993;83(1):38-41.

Vol. 61(3): 242 - 264, 2020 
95. Gómez Beltrán OD, Valverde Martínez A, Pérez Manrique M del C, Sánchez Rodríguez J, Lizárraga Febres E, Rufián Peña S. Superior mesenteric artery syndrome in a patient with Charcot Marie Tooth disease. World J Gastrointest Surg 2011;3(12):197-200.

96. Villalba Ferrer F, Vázquez Prado A, Artigues Sánchez de Rojas E, Garay Burdeos M, Martínez Sanjuán V, García Moneó $\mathrm{P}$, Trullenque Peris R. Diagnóstico de la compresión duodenal aorto-mesentérica mediante angiografía por resonancia magnética. Rev Esp Enferm Dig 1985;87(5):389-392.

97. Hernández-Gea V, García-Alba C, Soriano G, Pernas JC, Farré A. Coexistence of superior mesenteric artery syndrome and phytobezoar. J Gastrohep 2008;32(2):132134. https://doi.org/10.1016/j.gastrohep. 2008.09.012.

98. Sánchez Abuin J, Fernández Fernández JC, Rodríguez Sáenz de Buruaga V, Egaña Barrenechea JM. Tratamiento de la compresión vascular del duodeno mediante reimplante de la arteria mesentérica superior. Cir Esp 2010;87 (2):114-126.

99. Escartí Carbonell E, Cervera Delgado M. Dispepsia y síndrome de Wilkie, una causa poco frecuente, pero a menudo olvidada. $\mathrm{J}$ Gastrohep 2018;41(7),472-473. Https:// doi.org/10.1016/j.gastrohep.2018.02.005.

100. Núñez Gaviño P, Vázquez Ferro D, Bazarra Carou R, Deza Garrote T. Síndrome de la arteria mesentérica superior o síndrome de Wilkie. FMC 2013;20(2):114-115. Https:// doi.org/10.1016/S1134-2072(13)70536-X.

101. Irastorza-Terradillos I, Álvarez-Abad I, Santidrián-Martínez JI, Vitoria-Cormenzana JC. Dolor abdominal recurrente por síndrome de la arteria mesentérica superior. An Pediatr (Bare). 2010;73(3):150-1. https//doi/10.1016/j.anpedi.2010.05.023.

102. Alvarenga A, Espinheira C, Guerra P, Garcia M, Abreu M, Campos M. Superior mesenteric artery syndrome: weight loss can be a problem, weight gain can be a solution. GE Port J Gastroenterol 2017;24:43-46. Available from: https://www.karger.com/ Article/Pdf/450898.

103. Carvalho Lourenço L, Martins A, Oliveira AM, Valadas Horta D, Reis J. Wilkie Syndrome behind Crohn Disease? Superior mesenteric artery syndrome mimicking and complicating Crohn disease of the upper gastrointestinal tract. GE Port J Gastroenterol 2017;24:50-52. Doi: 10.1159/000450873. Available from: https://www.karger.com/ Article/Pdf/450873.

104. Catarino Santos S, Loureiro AR, Simão R, Pereira J, Pinheiro LF, Casimiro C. Wilkie's syndrome: a case report of favorable minimally invasive surgery. J Surg Case Rep 2018(2):1-4. https://doi.org/10.1093/ jser/rjy027.

105. Pereira IJ, Tavares C. Apertando o cinto: Síndrome de Wilkie e Síndrome de Nutcracker. Galicia Clin 2014; 75 (2): 82. Available from: https://dialnet.unirioja.es/descarga/ articulo/4794395.pdf.

106. Pires S, Veloso N, Dinis-Silva J. A Rare cause of proximal intestinal obstruction. GE Port J Gastroenterol 2016;23(3):175-176.

107. Rocha V, Lebre R, Ferreira P, Cardoso A, Augusto A. Síndroma da artéria mesentérica superior. A propósito de dois casos clínicos. Act Med Port 1993;6(1):47-50. Available from: https://www.actamedicaportuguesa.com/revista/index.php/amp/ article/download/3045/2387.

108. Silva E, Ribeiro C, Guerreiro S, Domíngues A. Síndrome de Wilkie - a propósito de um caso clínico. Rev Port Cir 2016;37:2528. Available from: http://www.scielo.mec. $\mathrm{pt} / \mathrm{pdf} / \mathrm{rpc} / \mathrm{n} 37 / \mathrm{n} 37 \mathrm{a} 05$.pdf.

109. Silva G, Moreira Silva H, Tavares M. Iatrogenic superior mesenteric artery syndrome. Rev Esp Enferm Dig 2018; 110(11):742-743. Available from: https://online.reed.es/downMaquetaArt. aspx?fed $=x 550.222872 \mathrm{Js}$.

110. Albano MN, Costa Almeida C, Louro JM, Martinez G. Increase body weight to treat superior mesenteric artery syndrome. BMJ Case Rep 2017; Doi: 10.1136/bcr-2017219378.

111. Townsend Jr. CM, Naoum JJ. Chapter 83. Vascular Compression of the Duodenum. In Fischer JE. Editors. Mastery of Surgery. 5th Edition Lippincott Williams \& Wilkins 2007. p. 955-961.

112. Akin JT Jr, Skandalakis JE, Gray SW. The anatomic basis of vascular compression of the duodenum. Surg Clin North Am 1974;54(6):1361-70. Https://doi. org/10.1016/S 0039-6109(16)40491-3. 
113. Velásquez-Jones $L$, Medeiros M, PatiñoOrtega M, Guerrero-Kanan R, Valadez-Reyes MT, Valverde-Rosas S, Moral-Espinosa I del, Franco-Alvarez I, Romo-Vázquez JC. Síndrome de cascanueces: causa de hematuria y proteinuria masiva no ǵlomerular. Bol Med Hosp Infant Mex 2014;71(5):298302. Available from: http://www.scielo.org. $\mathrm{mx} / \mathrm{pdf} / \mathrm{bmim} / \mathrm{v} 71 \mathrm{n} 5 / \mathrm{v} 71 \mathrm{n} 5 \mathrm{a} 7$.pdf.

114. Barsoum MK, Shepherd RF, Welch TJ. Patient with both Wilkie syndrome and nutcracker syndrome Vasc Med 2008;13(3):247-50. Doi: $10.1177 / 1358863 X 08092272$. Available from: https://journals.sagepub.com/ doi/pdf/10.1177/1358863X08092272.

115. Ahmed AR, Taylor I. Superior mesenteric artery syndrome. Postgrad Med J 1997;73(866):776-778. Doi: 10.1136/pg $m j .73 .866 .776$.

116. Guthrie Jr RH. Wilkie's Syndrome. Ann Surg 1971;173(2):290-293. Doi: 10.1097 /00000658-197102000-00017.

117. Paul JG, Eggleston FC, Singh CM. Acute intestinal obstruction secondary to vascular compression of the duodenum. Am J Surg 1973;126(5):658-660. Doi:10.1016/ s0002-9610(73)80016-9

118. Mathenge N, Osiro S, Rodriguen II, Salib C, Tubbs RS, Loukas M. Superior mesenteric artery syndrome and its associated gastrointestinal implications. Clin Anat 2014; 27 (8):1244-1252. Doi: 10.1002/ca.22249.

119. Veysi VT, Humphrey G, Stringer MD. Superior mesenteric artery syndrome presenting with acute massive gastric dilatation. J Pediatr Surg 1997;32(12):1801-1803. Doi: 10.1016/s0022-3468(97)90541-8.

120. Lim JE, Duke GL, Eachempati SR. Superior mesenteric artery syndrome presenting with acute massive gastric dilatation, gastric wall pneumatosis, and portal venous gas. Surgery 2003;134(5):840-843. Doi: 10.1016/s0039-6060(02)21677-3.

121. Agrawal GA, Johnson PT, Fishman EK. Multidetector row CT of superior mesenteric artery syndrome. J Clin Gastroenterol 2007;41(1):62-65. Doi: 10.1097/MCG. Ob013e31802dee64.

122. Lamba R, Tanner DT, Sekhon S, MeGahan JP, Corwin MT, Lall CG. Multidetector CT of vascular compression syndromes in the abdomen and pelvis [published correction appears in Radiographics 2015 ;35(3):973]. Radiographics 2014;34(1):93-115. Doi: 10. 1148/rg.341125010.

123. Gould R, Sandstrom CK, Strote J. Identification of superior mesenteric artery syndrome from vascular anǵle measurements. J Emerg Med 2015;49(1):e35-e36. Doi: 10.1016/j.jemermed.2014.12.087.

124. Kothari TH, Machnicki S, Kurtz L. Superior mesenteric artery syndrome. Can J Gastroenterol 2011;25(11):599-600. Doi: 10.1155/2011/617201.

125. Raman SP, Neyman EG, Horton KM, Eckhauser FE, Fishman EK. Superior mesenteric artery syndrome: spectrum of CT findings with multiplanar reconstructions and 3-D imaǵing. Abdom Imaǵing 2012;37(6):1079-1088. Doi: 10.1007/s00 261-012-9852-\%

126. Makary MS, Rajan A, Aquino AM, Chamarthi SK. Clinical and radiologic considerations for idiopathic superior mesenteric artery syndrome. Cureus 2017;9(11):e1822. Doi: 10.7759/cureus.1822. Available from: https://www.ncbi.nlm.nih.goov/pmc/articles/PMC5755943/

127. Narkiewicz-Jodko AS, Delaney VG, Braverman SE, Chow B. SMA Syndrome: A diaǵnostic dilemma. J Surg Radiol 2012; 3(1):16-19.

128. Konen E, Amitai M, Apter S, Garniek A, Gayer G, Nass S, Itzchak Y. CT anǵioǵraphy of superior mesenteric artery syndrome. Am J Roentǵenol 1998;171(5):1279_ 1281. DOI:10.2214/ajr.171.5.9798861.

129. Thompson NW, Stanley JC. Vascular Compression of the duodenum and peptic ulcer disease. Arch Surg 1974; 108(5): 674-679. Doi: 10.1001/archsurg. 1974.01350290038005.

130. Dalal S, Sahu R, Garg P, Nityasha. SMA Syndrome with peptic ulcer perforation: A rare co-existence. The Internet J Gastroenterol 2007;7(1):1-3. Available from: https://print.ispub.com/api/0/ispub-article/11403.

131. Giles RC. Chronic duodenal ileus. Am J Sur 1957;93(5):824-828. Doi: 10.1016/00029610(57)90557-3.

132. Bandres D, Brewer O, Roman O, Fernandez S. Wilkie's syndrome diaǵnosed by curvilinear array endoscopy ultrasound: an 
unsuspected entity. J Gastrointest Endoscop 2009; 69(2):S234. Doi: 10.1016/j.gie. 2008.12.097.

133. Long FR, Mutabagani KH, Caniano DA, Dumont RC. Duodenum inversum mimicking mesenteric artery syndrome. Pediatr Radiol 1999;29(8):602-604. Doi: 10.1007/ s002470050658.

134. Chandan S, Choudhry Chandan O, Hewlett AT. Duodenum inversum: a rare cause of chronic nausea and vomiting. Case Rep Gastrointest Med 2018;2018:7538601. Doi: 10.1155/2018/7538601.

135. Kim ME, Fallon, SC, Bisset GS, Mazziotti MV, Brandt ML. Duodenum inversum: A report and review of the literature. J Pediatr Surg 2013;48(1):e47-e49. Doi: 10.1016/j. jpedsurg.2012.10.066.

136. Welsch T, Büchler MW, Kienle P. Recalling superior mesenteric artery syndrome. Dig Surg 2007;24(3):149-156. Doi: 10.1159/000102097.

137. Colina-Cedeño OL, Trejo-Scorza E, BritoArreaza EJ. La compresión vascular del duodeno ó Síndrome de Wilkie en imágenes. Rev Cent Med 2019; 58(147): 17-21. Available from: https://www.revistacentromedico.org/ediciones/2019/1/art-3/

138. Lee TH, Lee JS, Jo Y. Superior mesenteric artery syndrome: where do we stand today? J Gastrointest Surg 2012;16(12):22032211. Doi: $10.1007 /$ s11605-012-2049-5

139. Jones SA, Carter R, Smith LL, Joergenson EJ. Arteriomesenteric duodenal compression. Am J Surg 1960; 100:262-277. Doi: 10.1016/0002-9610(60)90300-7.

140. Bloodgood JC. Acute dilatation of the stomach-gastromesenteric ileus. Ann Surg 1907;46(5):736-762.

141. Stavely AL. Chronic gastro-mesenteric ileus. Surg Gynecol 1910;11:288.

142. Strong EK. Mechanics of arteriomesenteric duodenal obstruction and direct surǵical attack upon etiology. Ann Surg 1958;148(5):725-730.
143. Alsulaimy M, Tashiro J, Perez EA, Sola JE. Laparoscopic Ladd's procedure for superior mesenteric artery syndrome. J Pediatr Surǵ 2014;49(10):1533-1535. Doi: 10.1016/j. jpedsurg.2014.07.008.

144. Bing L, Shun-Lin X, Ji-Hua O, Wei-Bing C, Ye-Bo W. Laparascopic Ladd's procedure as treatment alternative, when parenteral or prolonged hospital nutrition is not an option for superior mesenteric artery syndrome $\mathrm{J}$ Pediatr Surg 2017;S0022-3468(17)304165. Doi: 10.1016/j.jpedsurg.2017.07.004.

145. Marchant EA, Alvear DT, Fagelman KM. True clinical entity of vascular compression of the duodenum in adolescence. Surg Gynecol Obstet 1989;168(5):381-386.

146. Ha CD, Alvear DT, Leber DC. Duodenal derotation as an effective treatment of superior mesenteric artery syndrome: a thirty-three year experience. Am Surg 2008;74(7):644-653.

147. Pillay Y. Superior mesenteric artery syndrome:Acase report of two surgical options, duodenal derotation and duodenojejunostomy. Case Rep Vase Med 2016;2016:8301025. Doi: 10.1155/2016/8301025.

148. Hines JR, Gore RM, Ballantyne GH. Superior mesenteric artery syndrome. Diagnostic criteria and therapeutic approaches. Am J Surg 1984;148(5):630-632. Doi: 10.1016/0002-9610(84)90339-8.

149. Merrett ND, Wilson RB, Cosman P, Biankin AV. Superior mesenteric artery syndrome: diagnosis and treatment strategies. $\mathrm{J}$ Gastrointest Surg 2009;13(2):287-292. Doi: 10.1007/s11605-008-0695-4.

150. Salem A, Al Ozaibi L, Nassif SMM, Osman RAGS, Al Abed NM, Badri FM. Superior mesenteric artery syndrome: A diagnosis to be kept in mind (Case report and literature review). Int J Surg Case Rep 2017;34:8486. Doi: 10.1016/j.ijscr.2017.03.018. 